Danilo Dias Santana ${ }^{1}$

Ohttps://orcid. org/0000-0002-9769-7435

Diana Barbosa Cunha

Ohttps://orcid.org/0000-0003-0900-5628

Rosely Sichieri²

Ohttps://orcid.org/0000-0001-5286-5354

Gloria Valeria da Veiga' Ohttps://orcid.org/0000-0002-7985-0213

\section{Association of body image dissatisfaction with body mass index trajectory: the Adolescent Nutritional Assessment Longitudinal Study cohort}

\author{
Associação da insatisfação com a imagem corporal com a trajetória do índice de \\ massa corporal: Estudo Longitudinal de Avaliação Nutricional de Adolescentes
}

DOI: $10.1590 / 0047-2085000000279$

\begin{abstract}
Objective: To examine the association of body image dissatisfaction (BID) with body mass index (BMI) trajectory among students from a metropolitan area of Rio de Janeiro. Methods: Data were analyzed for 809 middle school students followed from 2010 to 2013, and 1131 high school students followed from 2010 to 2012. BID was assessed using a body silhouettes scale. Type of school (public and private) was used as a proxy of socioeconomic status. Results: In the middle school cohort, girls from private schools who wanted to have smaller and bigger silhouettes gained fewer BMI units than those who were satisfied with their body image $(p<0.05)$. In the high school, girls from private schools who wished to have bigger and smaller silhouettes experienced greater BMI increase than girls who were satisfied with their body image $(p<0.05)$. Also, in the high school cohort, boys from public schools who wished to have smaller and bigger silhouettes experienced smaller BMI increase than boys who were satisfied $(p<0.05)$. Conclusion: BID may be related to the BMI trajectory in girls from private schools and in boys from public schools.
\end{abstract}

\section{KEYWORDS}

Body image dissatisfaction, body mass index, adolescents, middle school, high school.

\section{RESUMO}

Objetivo: Examinar a associação da insatisfação com a imagem corporal (IIC) com a trajetória do índice de massa corporal (IMC) entre estudantes de uma região metropolitana do Rio de Janeiro. Métodos: Oitocentos e nove alunos do ensino fundamental foram acompanhados entre 2010 e 2013, e 1.131 alunos do ensino médio foram acompanhados de 2010 a 2012. A IIC foi avaliada por meio da escala de silhuetas corporais. O tipo de escola (pública e privada) foi utilizado como proxy do status socioeconômico. Resultados: Na coorte do ensino fundamental, as meninas de escolas particulares que desejavam ter silhuetas menores e maiores ganharam menos IMC do que aquelas que estavam satisfeitas com a imagem corporal $(p<0,05)$. No ensino médio, as meninas de escolas particulares que desejavam ter silhuetas menores e maiores experimentaram maior aumento do IMC do que as meninas que estavam satisfeitas $(p<0,05)$. Além disso, na coorte do ensino médio, meninos de escolas públicas que desejavam ter silhuetas menores e maiores experimentaram menor aumento no IMC do que meninos que estavam satisfeitos $(p<0,05)$. Conclusão: A IIC pode estar relacionada à trajetória do IMC em meninas de escolas particulares e meninos de escolas públicas.

\section{PALAVRAS-CHAVE}

Insatisfação com a imagem corporal, índice de massa corporal, adolescentes, ensino fundamental, ensino médio.
Received in: Apr/13/2020. Approved in: May/16/2020

1 Federal University of Rio de Janeiro (UFRJ), Institute of Nutrition Josué de Castro, Rio de Janeiro, RJ, Brazil.

2 State University of Rio de Janeiro (UERJ), Institute of Social Medicine, Rio de Janeiro, RJ, Brazil.

Address for correspondence: Danilo Dias Santana. Av. Carlos Chagas Filho, 373, llha do Fundão, CCS, Bloco J, $2^{\circ}$ andar. 21941-902 - Rio de Janeiro, RJ, Brasil.

E-mail: dias.danilo@hotmail.com 


\section{INTRODUCTION}

Body image dissatisfaction (BID) is defined as a body or shape negative self-evaluation, that is, the difference between the self-perceived body and the desired body by the individual'. A current scenario of pressure for thinness, whether transmitted by family members, media, or peers, often generates much anguish, especially in adolescents, whose characteristic is to follow leaders, groups, and fashions, in addition to the strong desire for acceptance and belonging to these social groups. Thus, adolescents are more likely to develop concerns about body and appearance ${ }^{2}$, making them more vulnerable to $\mathrm{BID}^{3}$.

This is an important problem because it may be closely linked to the onset of many common health problems in adolescence such as eating disorders, use of drugs for weight loss, and low self-esteem, which can interfere with weight gain throughout this stage of life ${ }^{4}$. In addition, studies argue that the growth process, characterised by the pubertal growth spurt and sexual maturation can interfere with the self-image of adolescents as different parts of the body grow at different rates during this period ${ }^{5}$, mainly in the first stage of adolescence, between 10 and 14 years old 6 .

International ${ }^{7,8}$ and national9 ${ }^{9-15}$ cross-sectional studies have investigated the association between BID and weight status in adolescents. Generally, the smaller silhouettes desire is associated with excess of weight, while the desire for bigger silhouettes is related with lower weight status. Besides that, body image issues as $\mathrm{BID}^{16}$ and weight/shape overvaluation ${ }^{17}$ has grown in modern society in which the number of individuals with overweight and obesity has increased significantly ${ }^{18}$. In this context, there is a paradox between the growing food offerings that favour the increase of obesity and the constant pressure to be thin ${ }^{19}$. The vulnerability to this pressure and, consequently, BID generally can be associated to weight status ${ }^{7-15}$, female gender, r, $^{9,20}$ and high socioeconomic level (mainly in adolescents from

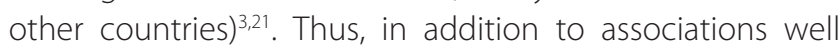
established in cross-sectional studies, we believe that dissatisfaction may be also associated with changes in the BMI trajectory in these groups during adolescence.

A Colombian longitudinal study using child-adapted body shape scales, found that BID was associated with changes in the BMI trajectory of school-age children (5-12 years) from public schools ${ }^{22}$. To the best of our knowledge, only this above-metioned study ${ }^{22}$ has investigated BID and BMI trajectory associations, but no one has investigated this association contemplating all the years of adolescence (10-19 years) in different socioeconomic contexts. It is necessary to highlight that in Brazil, country in which studies on the influence of socioeconomic level in body image are inconclusive ${ }^{21}$, it is important to study the association between BID and socioeconomic status where the type of school can be interpreted as a socioeconomic status proxy ${ }^{23,24}$.
The hypothesis that guides this study is that BID can interfere with weight changes over time, a process that can be more associated to female gender and possibly to higher socioeconomic status. Thus, this study aimed to examine the effect of BID on BMI trajectory among adolescents attending public and private schools from a metropolitan area of Rio de Janeiro, Brazil.

\section{METHODS}

\section{Study design and population}

A prospective study, the Adolescent Nutritional Assessment Longitudinal Study (ELANA), followed two cohorts of adolescents: a) those attending the sixth grade of middle school in 2010 (baseline), meaning early adolescence (mean age of $11.8 \pm 1.15$ years old), evaluated annually until 2013 and b) those attending the first grade of high school in 2010 (baseline), evaluated annually until 2012, meaning intermediate or late adolescence (mean age of $15.8 \pm 0.92$ years) ${ }^{23}$. Students in four private and two public schools located in the metropolitan region of Rio de Janeiro were evaluated. All students regularly admitted in the middle and high schools who met the eligibility criteria at baseline (having no physical or mental condition preventing completion of the questionnaire and assessment in anthropometric measures and not being pregnant or lactating) were invited to participate in the study.

The ELANA was approved by the Ethics Committee in Research of the Institute of Social Medicine of the State University of Rio de Janeiro (certificate number 0020.0.259.000-09). Participation was voluntary, and written informed consent was obtained from parents.

In the middle school, 809 of the 945 eligible students participated in baseline data collection (2010). At followup, the effective study sample comprised 648 students in 2011, 547 in 2012, and 488 in 2013. In the high school, 1039 of the 1131 eligible students participated in baseline data collection, and 789 participated in 2011 and 585 in 2012. The flowcharts of participants during the study are shown in figures 1 and 2.

\section{Measurements}

Anthropometric measures were performed by trained research assistants according to Lohman et al. ${ }^{25}$ protocols. Body weight was measured using an electronic and portable scale (Kratos ${ }^{\oplus}$ ) with a capacity of up to $150 \mathrm{~kg}$. Height was measured using a portable stadiometer (Alturexata ${ }^{\circledR}$ ) with a range of $0-213 \mathrm{~cm}$ and a variation of $0.1 \mathrm{~cm}$. Measurements were performed with adolescents without shoes and wearing light clothing, while standing fully upright, holding feet together, head in the Frankfurt plane, shoulders relaxed 


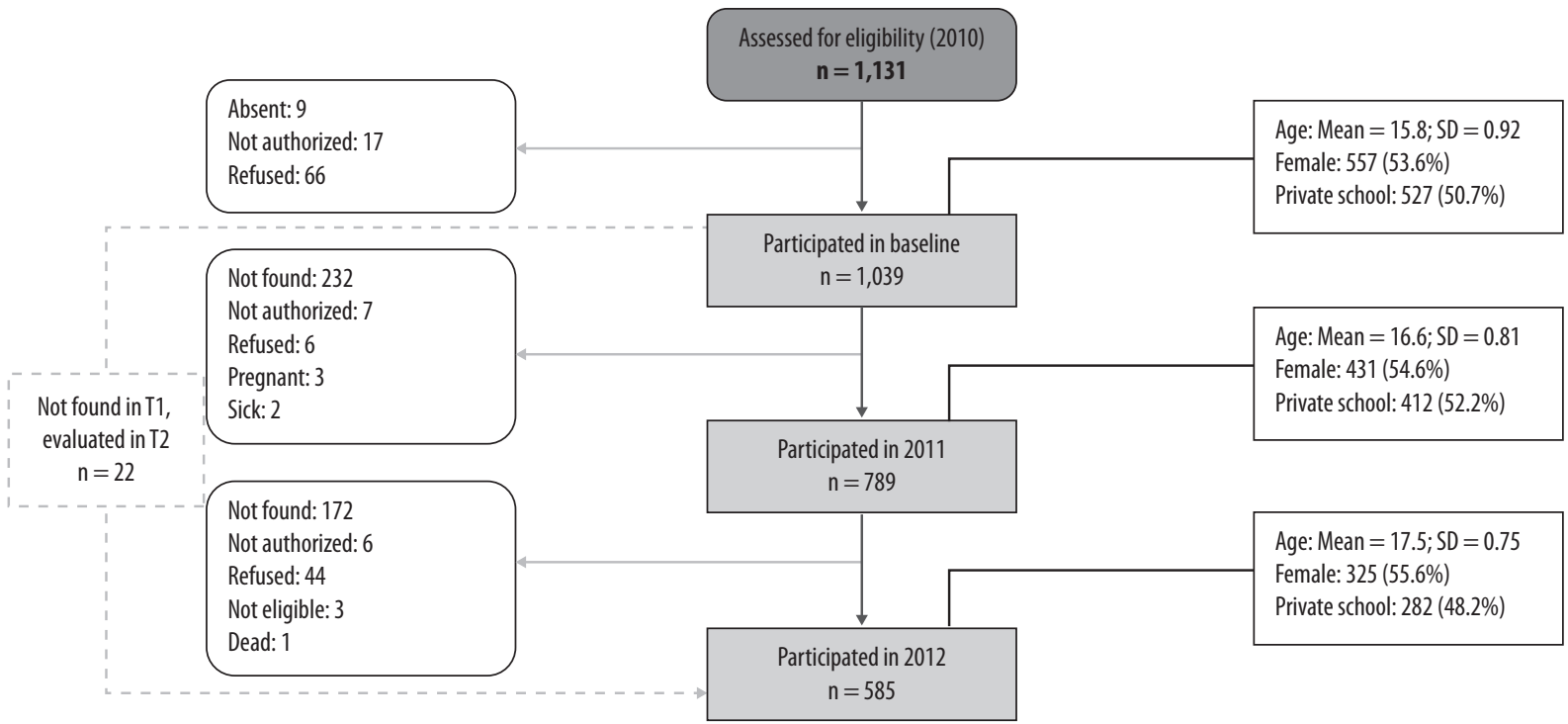

SD: standard deviation.

Figure 1. Flowchart of the middle school ELANA cohort selection.

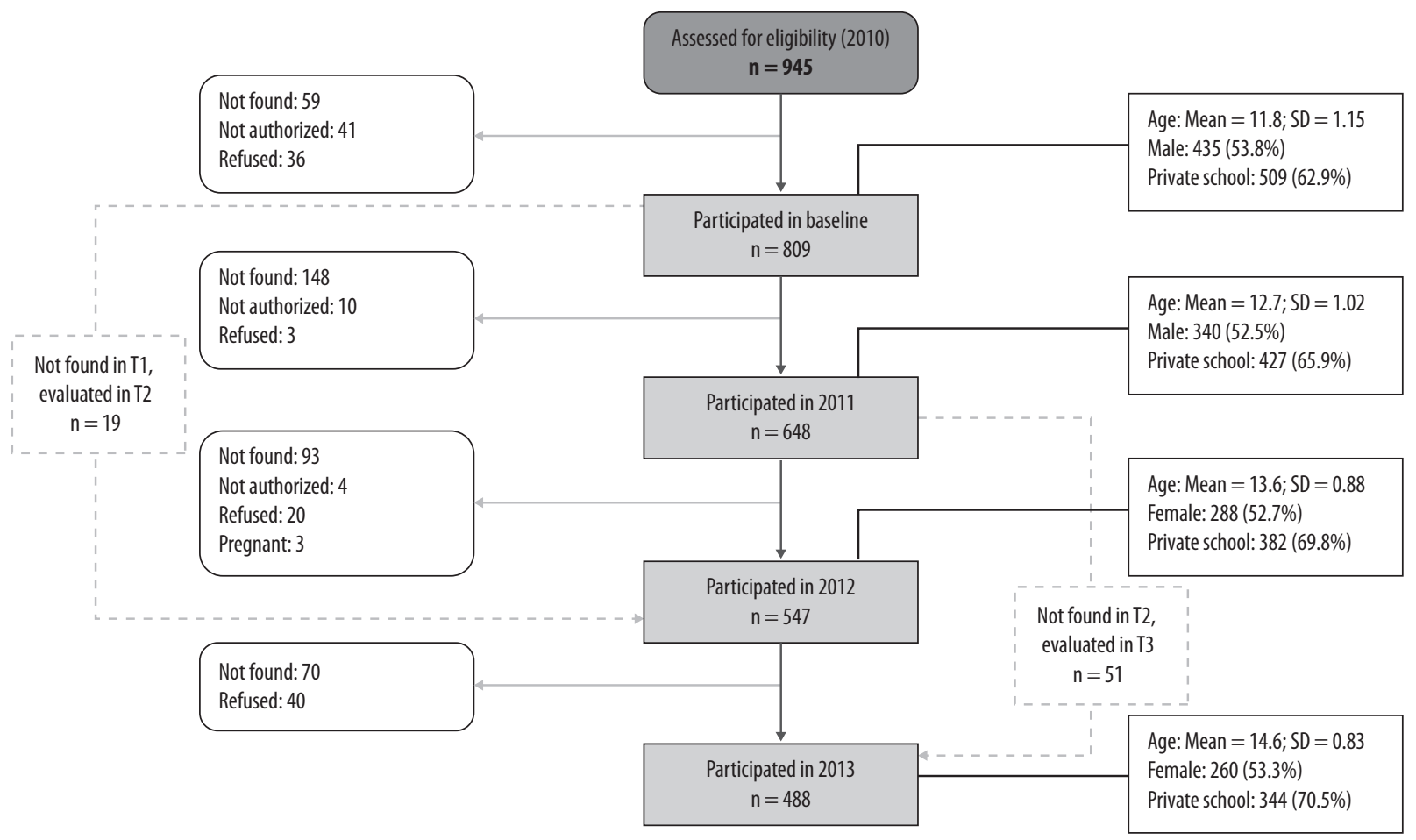

SD: standard deviation.

Figure 2. Flowchart of the high school ELANA cohort selection.

and arms hanging freely. Height was measured twice and repeated when the variation exceeded $0.5 \mathrm{~cm}$ between the two measurements. The mean of the measurements was used for analysis. The standardization of the field team for these measurements was made according to Habicht ${ }^{26}$ techniques at baseline and according to Pederson \& Gore techniques $^{27}$ in the other phases of the study $(2011,2012$ and 2013), which take into account the accuracy, validity and the technical error of the measurements.

Sociodemographic variables (age, sex, and type of school), sexual maturation, diet to lose weight, and BID data were obtained by self-report questionnaire. The field team was composed of graduated and post graduate students trained for the application, checking and quality control 
of the questionnaires. Field supervisors also explained to the students the procedure for completing self-report questionnaires, addressed their doubts, and checked each questionnaire to detect fill errors.

Sexual maturation stage was investigated at baseline only in the middle school cohort (considering that the greater body changes due to puberty occur in this age group) using the self-evaluation technique validated by Saito ${ }^{28}$ and focusing on the five stages of development of external genitalia for boys, breast development for girls and pubic hair for both, according to Tanner's criterion ${ }^{29}$.

Diet to lose weight at baseline was assessed by the question, "In the last three months, how often did you diet to control your weight?" The options for answers "never", "a few times", "often", and "always".

BID was also evaluated at baseline using the body silhouettes scale adapted for adolescents ${ }^{30}$, which comprises a set of nine silhouettes each for girls and boys ranging from the silhouette corresponding to extreme thinness to the silhouette corresponding to obesity ${ }^{31}$. The silhouettes were presented to adolescents with the following instructions: 1. "Select the figure you think you look the most like" and 2. "Select the figure you would most like to look like". BID was classified as the difference between the score corresponding to the silhouette they thought matched their current body (question 1) and the score corresponding to the silhouette they would like to have (question 2). The values of the differences could range from -8 to +8 , and greater the distance from the zero, greater is the degree of BID. It was considered that adolescents with negative values wished for bigger silhouettes and those with positive values wished for smaller silhouettes ${ }^{32}$.

\section{Data analysis}

In the descriptive analysis, the following baseline variables were presented by cohorts (middle or high school). BID was categorised into five groups: satisfaction with body image (0), bigger silhouettes slight desire $(-1)$, bigger silhouettes intense desire ( -2 to -8$)$, smaller silhouettes slight desire (1), and smaller silhouettes intense desire (2 to 8); BMI ( $\left.\mathrm{kg} / \mathrm{m}^{2}\right)$ was classified into four groups according to World Health Organization recommended age- and sex- standardised $z$-scores ${ }^{33}$ as follows: underweight $(<-2)$, normal weight ( $\geq-2$ to $\leq+1)$, overweight $(>+1$ to $\leq+2)$, and obese $(>+2)$; sex (male and female); type of school as proxy of socioeconomic status (public schools representing low socioeconomic level and private schools high socioeconomic status) ${ }^{23}$; diet to lose weight was categorised into two groups: no (never) and yes (a few times, often, always); and sexual maturation into five stages: from 1 to 5 breast/genitalia/ pubic hair categories.

Participants baseline data were compared by sex for each cohort and between those with one BMI measure and two or more BMI measures. Mean differences were compared using
Student's t-tests, and categorical variables were compared by chi-square test. These analyses were performed using the Statistical Program for the Social Sciences software, version 19.0 (SPSS, Chicago, IL).

BMI trajectories were analysed using linear mixed effect models through Proc Mixed command of the Statistical Analysis System, version 9.4 (SAS, Institute Inc, Cary, NC). This type of analysis allows accommodating correlations between repeated measurements as well as analysis for incomplete follow-up data on the outcome variable by considering the common effects of participants in the same group - fixed effects - and specific effects of each participant - random effects $^{34}$. The longitudinal analyses were stratified by type of school and sex.

To assess differences between changes in BMl over time according to the type of school and sex, an interaction term was used composed by age (used as a time effect) and the categorical variable of interest (Age $\times$ BID). The null hypothesis is that differences in BMI trajectories between BID levels would be constant over time. For this analysis, we assumed an unstructured variance-covariance pattern ${ }^{35}$. The trajectory analyses were adjusted by sexual maturation (stages 1 to 5 of genitalia for boys, breasts for girls and pubic hair for both) in middle school and diet to lose weight (yes or no) for middle and high school students at baseline.

\section{RESULTS}

In the middle school cohort boys were older than girls (11.9 vs. 11.7 years old, $p=0.002)$; presented more obesity $(22.2 \%$ vs. $14.0 \%, p=0.026)$; and were in more advanced stages of sexual maturation (stages 4 and 5 of the breast/genitalia/pubic hair classification). In the high school, boys were also older than girls (15.8 vs. 15.7 years old, $p=0.045$ ); also presented more obesity $(11.8 \%$ vs. $6.1 \%, p=0.012)$; and lower frequency of diet practice ( $30.5 \%$ vs. $49.1 \%, p<0.001$ ) (Table 1 ).

Regarding BID in the middle school, boys (44.5\%) and girls $(49.2 \%)$ presented similar frequencies $(p=0.690)$ of dissatisfaction (desire for smaller silhouettes). In the high school cohort, $31.2 \%$ of boys wanted smaller silhouettes while $50.4 \%$ of girls presented the same desire $(p<0.001)$, however the desire for bigger silhouettes was more frequent in boys $(41,2 \%)$ compared to girls $(27,1 \%, p<0.001)$ (Table 1$)$.

For loss of follow-up, it was noted that there were selective losses for both middle and high school cohorts. The mean age was higher for adolescents with only one $\mathrm{BMI}$ measurement, and there was more missing data in the public school. The proportion of adolescents who wanted to have bigger silhouettes ( -2 or less) was higher among those with only one BMI measurement (Table 2). 
Table 1. Sociodemographic factors, body mass index classification, sexual maturation, diet and body image dissatisfaction at baseline according to sex among students from middle and high schools

\begin{tabular}{|c|c|c|c|c|c|c|}
\hline & \multicolumn{2}{|c|}{ Middle school } & \multirow[b]{2}{*}{$\boldsymbol{p}^{\star}$} & \multicolumn{2}{|c|}{ High school } & \multirow[b]{2}{*}{$p^{*}$} \\
\hline & $\begin{array}{c}\text { Boys } \\
(n=435)\end{array}$ & $\begin{array}{c}\text { Girls } \\
(n=374)\end{array}$ & & $\begin{array}{c}\text { Boys } \\
(n=482)\end{array}$ & $\begin{array}{c}\text { Girls } \\
(n=557)\end{array}$ & \\
\hline Age (years) (mean \pm SD) & $11.9 \pm 1.2$ & $11.7 \pm 1.0$ & 0.002 & $15.8 \pm 0.9$ & $15.7 \pm 0.9$ & 0.045 \\
\hline \multicolumn{7}{|l|}{ Type of school (\%) } \\
\hline Private & 63.0 & 62.8 & 0.511 & 53.3 & 48.5 & 0.067 \\
\hline Public & 37.0 & 37.2 & & 46.7 & 51.5 & \\
\hline \multicolumn{7}{|l|}{ BMI classification (\%) } \\
\hline Low weight & 3.0 & 2.7 & 0.026 & 1.7 & 1.3 & 0.012 \\
\hline Adequate weight & $51.8^{* *}$ & $58.1^{*}$ & & $69.1^{* *}$ & $74.0^{* *}$ & \\
\hline Overweight & 23.0 & 25.2 & & 17.3 & 18.6 & \\
\hline Obesity & $22.2^{* *}$ & $14.0^{*}$ & & $11.8^{* *}$ & $6.1^{*}$ & \\
\hline \multicolumn{7}{|l|}{ Sexual maturation (\%)* } \\
\hline $\mathrm{B} 1 / \mathrm{G} 1$ & 4.9 & 6.2 & 0.004 & - & - & \\
\hline $\mathrm{B} 2 / \mathrm{G} 2$ & $26.0^{* *}$ & $32.2^{* *}$ & & - & - & \\
\hline B3/G3 & 41.8 & 43.1 & & - & - & \\
\hline B4/G4 & $21.3^{* *}$ & $16.8^{* *}$ & & - & - & \\
\hline B5/G5 & $6.0^{* *}$ & $1.6^{* *}$ & & - & - & \\
\hline \multicolumn{7}{|l|}{ Diet to lose weight (\%) } \\
\hline Yes & 47.6 & 45.9 & 0.346 & 30.5 & 49.1 & $<0.001$ \\
\hline No & 52.4 & 54.1 & & 69.5 & 50.9 & \\
\hline \multicolumn{7}{|l|}{ BID (\%) } \\
\hline Bigger silhouettes intense desire & 14.1 & 12.4 & 0.690 & $18.7^{* *}$ & $12.8^{* *}$ & $<0.001$ \\
\hline Bigger silhouettes slight desire & 15.2 & 12.7 & & $22.5^{* *}$ & $14.2^{* *}$ & \\
\hline Satisfied & 26.1 & 25.7 & & 27.6 & 22.6 & \\
\hline Smaller silhouettes slight desire & 18.9 & 20.8 & & $13.5^{*}$ & $25.0^{*}$ & \\
\hline Smaller silhouettes intense desire & 25.6 & 28.4 & & $17.7^{* *}$ & $25.4^{* *}$ & \\
\hline
\end{tabular}

BID: body image dissatisfaction: satisfied (0), bigger silhouettes slight desire $(-1)$, bigger silhouettes intense desire $(-2$ to -8$)$, smaller silhouettes slight desire (1), and smaller silhouettes intense desire (2 to 8). ${ }^{*}$ B/G: Breast/Genitalia classification of sexual maturation. BMl: body mass index; SD: standard deviation. ${ }^{*}$ Chi-square test. ${ }^{* *}$ Partitioning chi-square test: $p$ value < 0.05 .

Table 2. Characteristics of adolescents with only one body mass index measurement and those with two or more body mass index measurements

\begin{tabular}{|c|c|c|c|c|c|c|}
\hline & \multicolumn{3}{|c|}{ Middle school } & \multicolumn{3}{|c|}{ High school } \\
\hline & $\begin{array}{l}\text { Only one BMI } \\
\text { measurement } \\
(n=124)\end{array}$ & $\begin{array}{l}\text { Two or more BMI } \\
\text { measurements } \\
(n=679)\end{array}$ & $p^{*}$ & $\begin{array}{c}\text { Only one BMI } \\
\text { measurement } \\
(\mathrm{n}=232)\end{array}$ & $\begin{array}{l}\text { Two or more BMI } \\
\text { measurements } \\
(\mathrm{n}=794)\end{array}$ & $p^{*}$ \\
\hline \multicolumn{7}{|l|}{ Gender $(\%)$} \\
\hline Male & 58.1 & 53.2 & 0.182 & 50.9 & 45.2 & 0.075 \\
\hline Female & 41.9 & 46.8 & & 49.1 & 54.8 & \\
\hline Age (years) (mean \pm SD) & $12.5 \pm 1.6$ & $11.7 \pm 1.0$ & 0.000 & $16.2 \pm 1.1$ & $15.6 \pm 0.8$ & 0.000 \\
\hline \multicolumn{7}{|l|}{ Type of school (\%) } \\
\hline Private & 50.0 & 65.2 & 0.001 & 44.4 & 52.0 & 0.025 \\
\hline Public & 50.0 & 34.8 & & 55.6 & 48.0 & \\
\hline \multicolumn{7}{|l|}{ BMl classification (\%) } \\
\hline Low weight & 4.9 & 2.5 & 0.129 & 1.3 & 1.5 & 0.416 \\
\hline Adequate weight & 60.2 & 53.7 & & 72.2 & 71.6 & \\
\hline Overweight & 17.1 & 25.3 & & 15.4 & 18.8 & \\
\hline Obesity & 17.9 & 18.5 & & 11.0 & 8.1 & \\
\hline \multicolumn{7}{|l|}{ BID (\%) } \\
\hline Bigger silhouettes intense desire & $24.4^{* *}$ & $11.3^{* *}$ & 0.001 & $19.9^{* *}$ & $14.6^{* *}$ & 0.027 \\
\hline Bigger silhouettes slight desire & 11.4 & 14.5 & & 15.8 & 18.9 & \\
\hline Satisfied & 25.2 & 26.3 & & 29.0 & 23.9 & \\
\hline Smaller silhouettes slight desire & $13.0^{* *}$ & $20.9^{* *}$ & & $13.6^{* *}$ & $21.4^{* *}$ & \\
\hline Smaller silhouettes intense desire & 26.0 & 27.0 & & 21.7 & 21.2 & \\
\hline
\end{tabular}

BID: body image dissatisfaction: satisfied (0), bigger silhouettes slight desire $(-1)$, bigger silhouettes intense desire $(-2$ to -8$)$, smaller silhouettes slight desire (1), and smaller silhouettes intense desire (2 to 8). BMl: body mass index; m: mean; SD: standard deviation. * Chi-square test. * ${ }^{*}$ Partitioning chi-square test: $p$ value $<0.05$. 
Regarding BMI trajectories of the adolescents in middle school, it was noted that private school girls with slight desire for smaller silhouettes $\left(1.9 \mathrm{~kg} / \mathrm{m}^{2}\right)$ and those with slight desire for bigger silhouettes $\left(1.7 \mathrm{~kg} / \mathrm{m}^{2}\right)$ gained less BMI than girls who were satisfied $\left(2.8 \mathrm{~kg} / \mathrm{m}^{2}, p<0.05\right)$ (Table 3 and Figure 3 ).

In the high school cohort, girls from private schools with slight $\left(1.1 \mathrm{~kg} / \mathrm{m}^{2}\right)$ and intense $\left(1.4 \mathrm{~kg} / \mathrm{m}^{2}\right)$ desire for smaller silhouettes and those with intense desire for bigger silhouettes $\left(1.2 \mathrm{~kg} / \mathrm{m}^{2}\right)$ gained more BMI than girls who were satisfied $\left(0.5 \mathrm{~kg} / \mathrm{m}^{2}, p<0.05\right)$. In contrast, boys from public schools with slight desire for smaller silhouettes $\left(0.3 \mathrm{~kg} / \mathrm{m}^{2}\right)$ and slight $\left(0.9 \mathrm{~kg} / \mathrm{m}^{2}\right)$ and intense $\left(0.5 \mathrm{~kg} / \mathrm{m}^{2}\right)$ desire for bigger silhouettes experienced smaller BMI increase than boys who were satisfied $\left(1.3 \mathrm{~kg} / \mathrm{m}^{2}, p<0.05\right)$ (Table 4 and Figure 3$)$.

Table 3. Mean predicted values ${ }^{\dagger}$ of body mass index $\left(\mathrm{kg} / \mathrm{m}^{2}\right)$ by body image dissatisfaction levels of adolescents from middle school at baseline and follow-up, classified according to type of school and sex

\begin{tabular}{|c|c|c|c|c|c|c|c|c|}
\hline \multirow{3}{*}{ BID } & \multicolumn{8}{|c|}{ Private school } \\
\hline & \multicolumn{4}{|c|}{ Boys } & \multicolumn{4}{|c|}{ Girls } \\
\hline & Baseline & 2011 & 2012 & 2013 & Baseline & 2011 & 2012 & 2013 \\
\hline Bigger silhouettes intense desire & 16.4 & 16.8 & 17.1 & 17.7 & 16.1 & 16.6 & 17.3 & 17.9 \\
\hline Bigger silhouettes slight desire & 16.7 & 17.3 & 17.9 & 18.6 & $17.2^{*}$ & $17.9^{*}$ & $18.4^{*}$ & $18.9^{\circ}$ \\
\hline Satisfied & 19.1 & 19.7 & 20.4 & 21.0 & 17.6 & 18.5 & 19.5 & 20.4 \\
\hline Smaller silhouettes slight desire & 21.9 & 22.3 & 22.7 & 23.2 & $20.7^{*}$ & $21.4^{*}$ & $22.2^{*}$ & $22.6^{*}$ \\
\hline \multirow[t]{2}{*}{ Smaller silhouettes intense desire } & 24.3 & 24.8 & 25.4 & 26.0 & 23.9 & 24.5 & 25.3 & 25.9 \\
\hline & \multicolumn{8}{|c|}{ Public school } \\
\hline \multirow[t]{2}{*}{ BID } & \multicolumn{4}{|c|}{ Boys } & \multicolumn{4}{|c|}{ Girls } \\
\hline & Baseline & 2011 & 2012 & 2013 & Baseline & 2011 & 2012 & 2013 \\
\hline Bigger silhouettes intense desire & 17.3 & 17.5 & 17.9 & 18.4 & 18.4 & 18.7 & 18.6 & 19.3 \\
\hline Bigger silhouettes slight desire & 18.5 & 18.9 & 19.3 & 19.6 & 18.3 & 18.6 & 18.8 & 19.0 \\
\hline Satisfied & 19.0 & 19.4 & 19.7 & 20.1 & 19.2 & 19.5 & 19.9 & 20.1 \\
\hline Smaller silhouettes slight desire & 21.1 & 21.5 & 21.9 & 22.3 & 21.4 & 21.7 & 22.3 & 22.5 \\
\hline Smaller silhouettes intense desire & 25.3 & 25.5 & 26.1 & 26.4 & 23.8 & 24.2 & 24.6 & 24.9 \\
\hline
\end{tabular}

BID: body image dissatisfaction: satisfied (0), bigger silhouettes slight desire (-1), bigger silhouettes intense desire ( -2 to -8$)$, smaller silhouettes slight desire (1), and smaller silhouettes intense desire (2 to 8). "All categories compared to level 0 (satisfied), $p<0.05$. ${ }^{\dagger}$ Model of interaction: body mass index $=$ age $\times$ BID, adjusted by sexual maturation and diet to lose weight.

Table 4. Mean predicted values ${ }^{\dagger}$ of body mass index $\left(\mathrm{kg} / \mathrm{m}^{2}\right)$ by body image dissatisfaction levels of adolescents from high school at baseline and follow-up, classified according to type of school and sex

\begin{tabular}{|c|c|c|c|c|c|c|}
\hline \multirow{3}{*}{ BID } & \multicolumn{6}{|c|}{ Private school } \\
\hline & \multicolumn{3}{|c|}{ Boys } & \multicolumn{3}{|c|}{ Girls } \\
\hline & Baseline & 2011 & 2012 & Baseline & 2011 & 2012 \\
\hline Bigger silhouettes intense desire & 18.8 & 19.4 & 20.0 & $18.0^{*}$ & $18.6^{*}$ & $19.2^{*}$ \\
\hline Bigger silhouettes slight desire & 19.6 & 20.2 & 20.9 & 19.3 & 19.5 & 19.8 \\
\hline Satisfied & 21.6 & 22.3 & 23.1 & 20.3 & 20.5 & 20.8 \\
\hline Smaller silhouettes slight desire & 23.3 & 24.0 & 24.8 & $22.5^{*}$ & $23.0^{*}$ & $23.6^{*}$ \\
\hline \multirow[t]{2}{*}{ Smaller silhouettes intense desire } & 28.1 & 28.8 & 29.2 & $25.4^{*}$ & $26.1^{*}$ & $26.8^{*}$ \\
\hline & \multicolumn{6}{|c|}{ Public school } \\
\hline \multirow[t]{2}{*}{ BID } & \multicolumn{3}{|c|}{ Boys } & \multicolumn{3}{|c|}{ Girls } \\
\hline & Baseline & 2011 & 2012 & Baseline & 2011 & 2012 \\
\hline Bigger silhouettes intense desire & $19.3^{*}$ & $19.5^{*}$ & $19.8^{*}$ & 18.4 & 18.8 & 19.3 \\
\hline Bigger silhouettes slight desire & $19.8^{*}$ & $20.2^{*}$ & $20.7^{*}$ & 19.6 & 19.9 & 20.3 \\
\hline Satisfied & 21.7 & 22.2 & 23.0 & 21.2 & 21.6 & 22.0 \\
\hline Smaller silhouettes slight desire & $24.3^{*}$ & $24.5^{+}$ & $24.6^{*}$ & 23.0 & 23.6 & 24.3 \\
\hline Smaller silhouettes intense desire & 28.0 & 28.6 & 29.2 & 26.0 & 26.2 & 26.5 \\
\hline
\end{tabular}

BID: body image dissatisfaction: satisfied (0), bigger silhouettes slight desire $(-1)$, bigger silhouettes intense desire $(-2$ to -8$)$, smaller silhouettes slight desire (1), and smaller silhouettes intense desire (2 to 8). "All categories compared to level 0 (satisfied), $p<0.05$. ${ }^{\dagger}$ Model of interaction: body mass index $=$ age $\times$ BID, adjusted by diet to lose weight. 

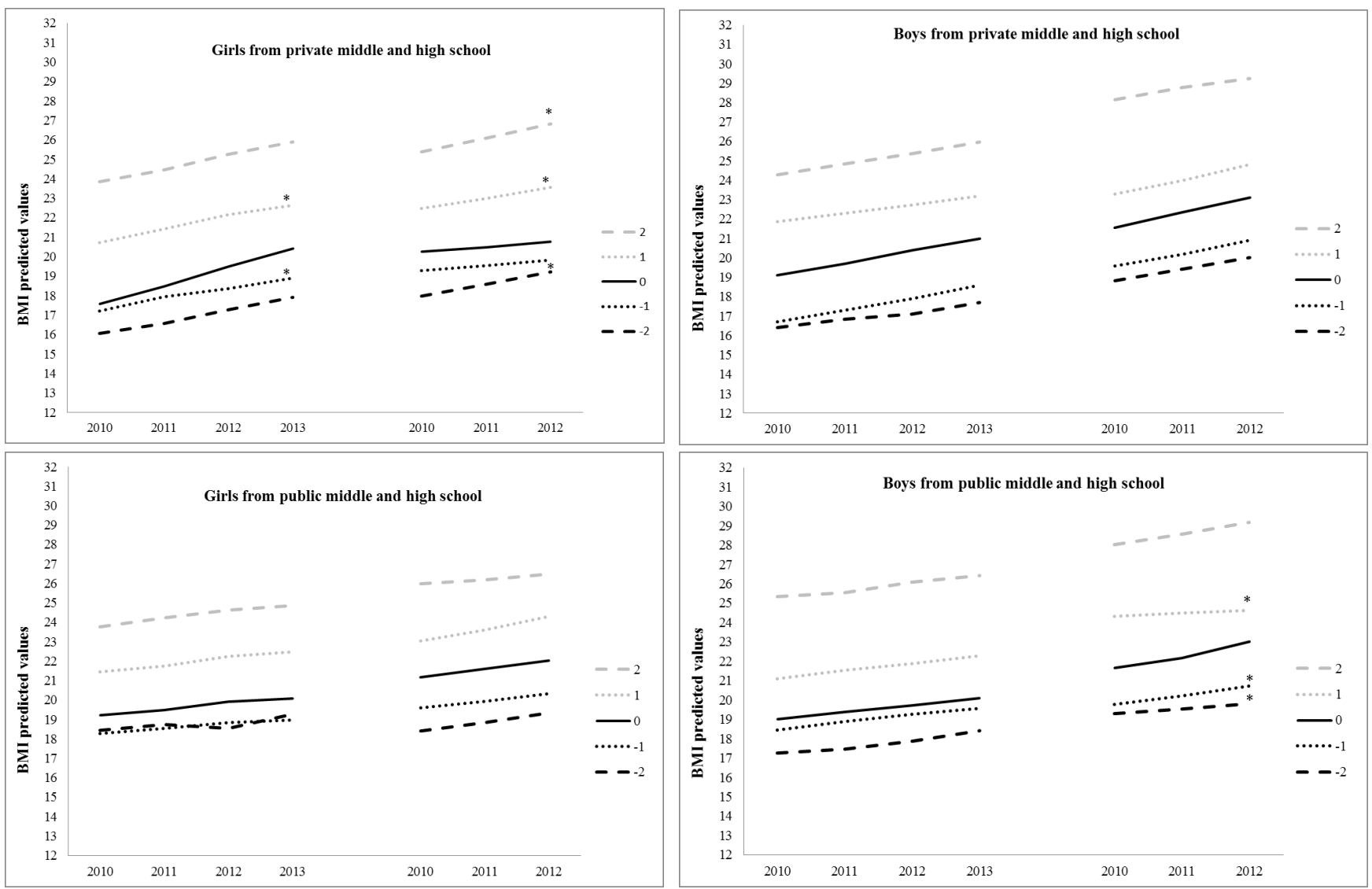

Figure 3. Estimated BMI change according to BID in adolescents from Rio de Janeiro, Brazil. BMI: body mass index; BID: body image dissatisfaction: satisfied (0), bigger silhouettes slight desire (-1), bigger silhouettes intense desire ( -2 to -8$)$, smaller silhouettes slight desire (1), and smaller silhouettes intense desire (2 to 8). ${ }^{*} p<0.05$. Model of interaction: BMI = age $\times$ BID, adjusted by sexual maturation (middle school) and diet to lose weight.

\section{DISCUSSION}

The main result of this research is that BID had a significant effect on BMl gain during the follow-up study in girls from private schools. Given that, in Brazil, the variable type of school, public or private, has been interpreted as a proxy for socioeconomic status 23,24 , it is suggested that girls with higher socioeconomic level are more vulnerable to the BID and BMI trajectory associations. To verify these relations is important because BID generated by not achieving the 'ideal body' can lead to inappropriate dietary behaviours and further jeopardise BMI gain as an indicator of growth.

This greater vulnerability of individuals with higher socioeconomic status related to body image issues was verified in Brazil by Felden et al..$^{36}$ in a study with high school students. Adolescents whose head of household had higher levels of education (socioeconomic status proxy) were more likely to have BID. In Mexico, Bojorquez et al. ${ }^{37}$, also noted that students whose mothers had higher education levels were more likely to perceive themselves as having overweight. This perception may be related to an increased likelihood of the individual presenting BID.
The effects of BID on the BMI trajectory, which were more present in female participants in this study, may be related to the fact that girls are more vulnerable to BID, as has already been verified in cross-sectional studies. Santana et al. ${ }^{9}$, noted that the girls had higher prevalence of BID than boys from public schools in Salvador city, Brazil. Pelegrini et al. ${ }^{10}$ also noted that female adolescents were more susceptible to BID, particularly wishing to have smaller silhouettes. However, regarding our data, it is necessary to highlight that in middle school, boys and girls presented similar frequencies of desire for bigger silhouettes. In high school, while most girls whished smaller silhouettes, boys wanted bigger silhouettes, showing that adolescents of different age groups and sex may differ in relation to the direction of their dissatisfaction.

Girls from private middle schools wishing to have smaller and bigger silhouettes showed lower BMI gain curves than girls who were satisfied, regardless of whether they were dieting to lose weight. In this period of adolescence, the pubertal growth spurt occurs and this is a phase of intense physical and psychological changes ${ }^{38}$, in addition to being a period with greater energy demand given the rapid growth. If these adolescents have irregular eating with, for example, 
omission of meals, their BMl gain may vary regardless of BID. Future studies investigating food consumption of students in this context may clarify these associations.

Private high school girls also showed associations between BMI gain and BID but in the opposite direction of what was noted in middle school girls. Those who wished to have smaller and bigger silhouettes, presented more accentuated BMI gain curves than girls who were satisfied with their body image. These associations may suggest that, with advancing age and the end of the pubertal growth spurt ${ }^{39}$, there is greater difficulty in losing or maintaining weight.

It was also noted that boys from public high schools who wished to have smaller and bigger silhouettes had lower $\mathrm{BMI}$ increase than those who were satisfied. A hypothesis for this scenario is that boys from public school, who have worse socioeconomic conditions in Brazil ${ }^{23,24}$, can present less physical development and, consequently, reduced gain of BMI. Furthermore, another study performed in the same cohort noted that boys from public schools presented less gain of BMI than boys from private schoo ${ }^{13}$.

Only one longitudinal research was found with an objective similar to the present study. Duchin et al..$^{22}$ followed a children cohort from public schools in Bogotá with an average of 8 years old at baseline until 14 years old, and BID was assessed using the body silhouettes scale. It was found that, regardless of their BMI status for age and their desire for bigger or smaller silhouettes, dissatisfied boys gained more BMI compared to satisfied ones, while dissatisfied girls gained less BMI compared those who were satisfied. Despite the methodological differences between the two studies (ours and Duchin et al.22), which limit the comparison of the results, it should be noted that, in both studies, BID interferes in weight gain over time, but wish to have a bigger or smaller silhouette does not seem to be directly related to the direction of that gain. It is also important to highlight that the BMI gain of the adolescents investigated in this study, regardless of the degree of $B I D$, was within the range of healthy $\mathrm{BMI}$ gain for age recommended by the $\mathrm{WHO}^{33} \mathrm{BMI}$ curves for adolescents.

It is worth highlighting the relationship between BID and BMI classification of the adolescents at baseline. Higher the BMI was, higher was the level of BID (desire to have smaller silhouettes). On the other hand, adolescents with lower BMI at baseline also had higher levels of dissatisfaction, wishing to have larger silhouettes. National9 $\left.\right|^{9-15}$ and international studies 7,8 have found a correlation between BID and weight status similar to the present study, especially in adolescents with overweight. In this study, approximately $75 \%$ of adolescents had some level of dissatisfaction. Other studies found similar frequency (between 70\% and 75\%) 7,10 using the same method for assessing BID. These high frequencies are worrying, because BID, especially during adolescence, may be closely linked to the onset of many health problems common in adolescence such as eating disorders, drug use for weight loss, and low self-esteem ${ }^{4,40}$.

The results of this study should be analysed in light of its limitations and strengths. There was loss of information on adolescents throughout the follow-up for both cohorts. However, in the BMI trajectory analysis, mixed effect models were used to consider all available data, and $84.6 \%$ (middle school) and $77.4 \%$ (high school) contributed data for two waves. Differential follow-up losses during the study for age mean (biggest loss for old ones), type of school (biggest loss in public schools), and BID were noted. The lack of information on the exposure variable (BID) as well as the adjustment variables (sexual maturation and diet to lose weight) in all phases of the study, precluding control for changes in these variables over time is another possible limitation.

We also highlight the method of evaluation of BID based on the body silhouettes scale. According to Gardner et al. ${ }^{41}$, the high number and similarity of silhouettes could confuse the identification of adolescents' current and desired images. However, this scale was considered more appropriate to ELANA, because it could avoid difficulties in understanding long and complex questionnaires that are usually applied to adolescents for this purpose. Furthermore, despite the silhouettes scale being considered by some authors a crude scale, this method of evaluation has some reliability ${ }^{42}$ and has been widely used in other epidemiological researches ${ }^{43-45}$. As the study's strength, to our knowledge, this is a pioneering study with the objective to determine the influence of BID in the BMI trajectory of students in both phases of adolescence and in different social contexts.

\section{CONCLUSIONS}

It was concluded that BID may be related to BMI gain in different phases of adolescence, mainly in girls with high socioeconomic status. Furthermore, the high frequency of dissatisfaction found in both sexes may indicate the need for actions that encourage the enhancement of body image among adolescents to minimise behaviours such as eating disorders, use of drugs for weight loss, and low self-esteem.

\section{INDIVIDUAL CONTRIBUTIONS}

Danilo Santana - Wrote the first draft of the manuscript.

Rosely Sichieri and Gloria Veiga - Conceived and designed the ELANA Project.

Danilo Santana, Diana Cunha and Rosely Sichieri Performed specific longitudinal analyses. The conception, 
design and interpretation of this paper data were performed by all authors.

\section{CONFLICT OF INTERESTS}

The authors have no conflict of interests to disclose.

\section{ACKNOWLEDGEMENTS}

None.

\section{ETHICAL APPROVAL AND CONSENT TO PARTICIPATE}

All procedures performed in studies involving human participants were in accordance with the ethical standards of the institutional and/or national research committee and with the 1964 Helsinki declaration and its later amendments or comparable ethical standards. Informed consent was obtained from all individual participants included in the study.

\section{FUNDING}

This work was supported by the National Council for Scientific and Technological Development (grant number 47667/2011-9); the Research Support Foundation of the State of Rio de Janeiro (grant numbers grants E26/110.847/2009, E26/110.626/2011 and E-26/110.774/2013); and the Coordination for the Improvement of Higher Education Personnel (grant number 23038.007702/2011-5).

\section{AVAILABILITY OF DATA AND MATERIALS}

The datasets used and/or analysed during the current study are available from the corresponding author on reasonable request.

\section{REFERENCES}

1. Mitchison D, Hay P, Griffiths S, Murray SB, Bentley C, Gratwick-Sarll K, et al. Disentangling body image: The relative associations of overvaluation, dissatisfaction, and preoccupation with psychological distress and eating disorder behaviors in male and female adolescents. Int J Eat Disord. 2017;50(2):118-26.

2. Smolak L. Risk factors in the development of body image, eating problems, and obesity. In: Smolak L, Thompson JK, editors. Body Image, Eating Disorders, and Obesity in Youth: Assessment, Prevention, and Treatment. Washington: American Psychological Association; 2009. p. 133-5.
3. Alves $E$, Vasconcelos FA, Calvo MC, Neves J. [Prevalence of symptoms of anorexia nervosa and dissatisfaction with body image among female adolescents in Florianopolis, Santa Catarina State, Brazil]. Cad Saude Publica. 2008;24(3):503-12.

4. Hrabosky Jl, Grilo CM. Body image and eating disordered behavior in a community sample of Black and Hispanic women. Eat Behav. 2007;8(1):106-14.

5. Amaral ACS, Andrade MRM, Oliveira TP, Madeira HA, Ferreira MEC [The culture of the ideal body: body satisfaction level among students of different age groups - a comparative study]. HU Rev. 2007;33(2):41-5.

6. World Health Organization. Physical status: the use and interpretation of anthropometry. Report of a WHO Expert Committee. World Health Organ Tech Rep Ser. 1995;854:1-452.

7. Chen LJ, Fox KR, Haase AM. Body shape dissatisfaction and obesity among Taiwanese adolescents. Asia Pac J Clin Nutr. 2008;17(3):457-60.

8. Lawler M, Nixon E. Body dissatisfaction among adolescent boys and girls: the effects of body mass, peer appearance culture and internalization of appearance ideals. J Youth Adolesc. 2011;40(1):59-71.

9. Santana ML, Silva RC, Assis AM, Raich RM, Machado ME, Pinto E, et al. Factors associated with body image dissatisfaction among adolescents in public schools students in Salvador, Brazil. Nutr Hosp. 2013;28(3):747-55.

10. Pelegrini A, Coqueiro R, Beck C, Ghedin K, Lopes A, Petroski EL. Dissatisfaction with body image among adolescent students: association with socio-demographic factors and nutritional status. Ciênc Saúde Coletiva. 2014;19(4):1201-8.

11. Lepsen AM, Silva M. Prevalência e fatores associados à insatisfação com a imagem corporal de adolescentes de escolas do ensino médio da zona rural da região sul do Rio Grande do Sul, 2012. Epidemiol Serv Saúde. 2014;23(2):317-25.

12. Santos MLB, Novaes JS, Monteiro L, Fernandes HM. [Body dissatisfaction and life quality during the menarche and its relation to the family income and the body mass index: A longitudinal study]. Motricidade. 2015;11(2):75-84.

13. Cubrelati BS, Rigoni PAG, Vieira LF, Belem IC. Relationship between body image distortion and risk of developing eating disorders in adolescents. Revista da Faculdade de Educação Física da Unicamp. 2014;12(1):1-15.

14. Glaner M, Pelegrini A, Cordoba OC, Pozzobon EM. Association between body image dissatisfaction and anthropometric indicators in adolescents. Rev Bras Educ Fís Esporte. 2013;27(1):129-36.

15. Laus MF, Costa TMB, Almeida SS. Body image dissatisfaction and its relationship with physical activity and body mass index in Brazilian adolescents. J Bras Psiquiatr. 2011;60(4):315-20.

16. Kvalem IL, Traeen B, Markovic A, von Soest T. Body Image Development and Sexual Satisfaction: A prospective study from adolescence to adulthood. J Sex Res. 2019;56(6):791-80.

17. Santana DD, Mitchison D, Griffiths S, Appolinario JC, da Veiga GV, Touyz S, et al. Ten-year time trends in mental and physical health correlates of weight/shape overvaluation. Eur Eat Disord Rev. 2019:27:531-40.

18. Instituto Brasileiro de Geografia e Estatística (IBGE). National Household Budget Survey: 2008/2009. Anthropometry and Nutritional Status of Children, Adolescents and Adults in Brazil. Rio de Janeiro: IBGE; 2010.

19. Oliveira F, Bosi M, Vigário P, Vieira R. Comportamento alimentar e imagem corporal em atletas. Rev Bras Med Esporte. 2003;9(6):348-56.

20. Gillen MM, Lefkowitz ES. Gender and racial/ethnic differences in body image development among college students. Body image. 2012;9(1):126-30.

21. Pereira EF, Teixeira CS, Gattiboni BD, Bevilacqua LA, Confortin SC, Silva TR. Percepção da imagem corporal e nível socioeconômico em adolescentes: revisão sistemática. Rev Paul Pediatr. 2011;29(3):423-9.

22. Duchin 0, Marin C, Mora-Plazas M, Mendes de Leon C, Lee JM, Baylin A, et al. A prospective study of body image dissatisfaction and BMI change in school-age children. Public Health Nutr. 2015;18(2):322-8.

23. Moreira NF, Sichieri R, Reichenheim ME, Oliveira AS, Veiga GV. The associations of BMI trajectory and excessive weight gain with demographic and socio-economic factors: the Adolescent Nutritional Assessment Longitudinal Study cohort. Br J Nutr. 2015;114(12):2032-8.

24. Suñé FR, Dias-da-Costa JS, Olinto MT, Pattussi MP. [Prevalence of overweight and obesity and associated factors among schoolchildren in a southern Brazilian city]. Cad Saude Publica. 2007;23(6):1361-71. 
25. Lohman TG, Roche A, Martorell R. Anthropometric Standardization Reference Manual. Champaign: Human Kinetics Press; 1988.

26. Habicht, JP. [Standardization of quantitative epidemiological methods in the field]. Bol Oficina Sanit Panam. 1974;76(5):375-84

27. Pederson D, Gore C Anthropometry measurement error. In: Norton K, Olds T, editors. Antropometrica. Sydney: University of New South Wales Press; 1996. p. 77-96.

28. Saito MI. Sexual maturity: self-evaluation of the adolescent. Pediatria. 1984;6:111-5.

29. Tanner JM. Growth at Adolescence. 2nd ed. Oxford: Blackwell Scientific publication; 1962.

30. McElhone S, Kearney JM, Giachetti I, Zunft HJ, Martinez JA. Body image perception in relation to recent weight changes and strategies for weight loss in a nationally representative sample in the European Union. Public Health Nutr. 1999;2(1A):143-51.

31. Madrigal-Fritsch $H$, Irala-Estevez J, Martinez-Gonzalez MA, Kearney J, Gibney $M$, Martinez-Hernandez JA. [The perception of body image as a qualitative approach to nutritional status]. Salud Publ Mex. 1999;41(6):479-86.

32. Ribeiro LG, Veiga GV. Imagem corporal e comportamentos de risco para transtornos alimentares em bailarinos profissionais. Rev Bras Med Esporte. 2010;16(2):99-102.

33. de Onis M, Onyango AW, Borghi E, Siyam A, Nishida C, Siekmann J. Development of a WHO growth reference for school-aged children and adolescents. Bull World Health Organ. 2007:85:660-7.

34. Spyrides MAC, Struchiner CJ, Barbosa MT, Kac G. Data analysis with repeated measures. In: Kac G, Sichieri R, Gigante DP, editors. Nutritional Epidemiology. Rio de Janeiro: Fiocruz e Atheneu; 2007. p. 245-60

35. Fitzmaurice GM, Laird NM, Ware JH. Longitudinal and clustered data. In: Fitzmaurice GM, Laird NM, Ware JH, editors. Applied Longitudinal Analysis. New Jersey: John Willey and Sons; 2011. p. 1-18.
36. Felden EP, Claumann GS, Sacomori C, Daronco LS, Cardoso FL, Pelegrini A. [Sociodemographic factors and body image among high school students]. Ciênc Saúde Coletiva. 2015;20(11):3329-37.

37. Bojorquez I, Villatoro J, Delgadillo M, Fleiz C, Fregoso D, Unikel C. Social factors, weight perception, and weight control practices among adolescents in Mexico. J Health Psychol. 2018;23(7):939-50

38. Arthur NA, Gowland RL, Redfern RC. Coming of age in Roman Britain: Osteological evidence for pubertal timing. Am J Phys Anthropol. 2016;159(4):698-713.

39. Chelala CA. [Health of adolescents and youth in the Americas: writing the future]. Washington, DC: Organización Panamericana de La Salud; 1995.

40. Ricciardelli LA, McCabe MP. Children's body image concerns and eating disturbance: a review of the literature. Clin Psychol Rev. 2001;21(3):325-44.

41. Gardner RM, Friedman BN, Jackson NA. Methodological concerns when using silhouettes to measure body image. Percept Mot Skills. 1998;86(2):387-95.

42. Mutale G, Dunn A, Stiller J, Larkin R. Development of a Body Dissatisfaction Scale Assessment Tool. New School Psychol Bull. 2016;13:47-57.

43. Araujo TS, Barbosa Filho VC, Gubert FDA, de Almeida PC, Martins MC, Carvalho QG, et al. Factors Associated With Body Image Perception Among Brazilian Students From Low Human Development Index Areas. J Sch Nurs. 2018;34(6):449-57.

44. Ganesan S, Ravishankar SL, Ramalingam S. Are Body Image Issues Affecting Our Adolescents? A Cross-sectional Study among College Going Adolescent Girls. Indian J Community Med. 2018;43(Suppl 1):S42-6.

45. Shaban L, Vaccaro J, Sukhram S, Huffman F. Perceived Body Image, Eating Behavior, and Sedentary Activities and Body Mass Index Categories in Kuwaiti Female Adolescents. Int J Pediatr. 2016;2016::1092819 


\section{Association of body image dissatisfaction with body mass index trajectory: the Adolescent Nutritional Assessment Longitudinal Study cohort}

Associação da insatisfação com a imagem corporal com a trajetória do índice de massa corporal: Estudo Longitudinal de Avaliação Nutricional de Adolescentes

DOl: 10.1590/0047-2085000000279

Where you read:

Received in: May/16/2020. Approved in: May/19/2020

Should read:

Received in: Apr/13/2020. Approved in: May/16/2020

DO1: 10.1590/0047-2085000000319 